\title{
Erratum to: Oral doxycycline for the treatment of chronic leg ulceration
}

Genevieve M. Sadler · Hilary J. Wallace • Michael C. Stacey

Published online: 1 February 2012

(C) Springer-Verlag 2012

\section{Erratum to: Arch Dermatol Res}

DOI 10.1007/s00403-011-1201-5

We regret that there was significant omission of doxycycline concentrations units in Abstract and Discussion sections of online published article. The units for both the low dose and high dose groups are as follows: $0.2 \mathrm{mg} / \mathrm{L}$ $(0.45 \mu \mathrm{M})$ and $2.3 \mathrm{mg} / \mathrm{L}(5.18 \mu \mathrm{M})$.

The online version of the original article can be found under doi:10.1007/s00403-011-1201-5.

G. M. Sadler $(\bowtie)$

Department of Dermatology, Sir Charles Gairdner Hospital, Hospital Ave, Nedlands, WA 6009, Australia

e-mail: gen_sadler@xcitelogic.com.au

H. J. Wallace

Burn Injury Research Unit, School of Surgery,

University of Western Australia, Crawley, Australia

M. C. Stacey

School of Surgery, Fremantle Hospital,

University of Western Australia, Fremantle, Australia 